Infusionstherapie 1987;14(Suppl. 5):1

\title{
Contents, Vol. 14, Supplement 5, 1987
}

\section{Imprint}

29

Giovannetti, S., Pisalltalien

Compliance und Ernährungszustand von Patienten unter einer eiweißarmen, mit Amino-/Ketosäuren supplementierten Diät . . tröm, J.; Ahlberg, M. und

Alvestrand, A., Stockholm!Schweden; Fürst, P., Stuttgart

Aminosäurentherapie bei Patienten mit chronischem Nierenversagen

Barsotti, G.; Navalesi, R.; Morelli, E,; Giampietro, O.;

Ciardella, F.; Cupísti, A. und Giovannetti, S., Pisalltalien

Einfluß einer phosphat- und eiweißarmen Diät, supplementiert

mit essentiellen Aminosäuren und Ketoanaloga, auf die fortgeschrittene diabetische Nephropathie

12

Walser, M.; LaFrance, N.; Ward, L. und

VanDuyn, Baltimore/USA

Die Progression chronischer Niereninsuffizienz nach der Gabe

von Ketosäuren und Aminosäuren

17

Gretz, N.; Meisinger, E. und Strauch, M., Mannheim

Der Einfluß von Diät und renaler Grunderkrankung auf die

Progression der chronischen Niereninsuffizienz 21

Meisinger, E.; Gretz, N. und Strauch, M., Mannheim

Hyperfiltration unter eiweißarmer Diät induziert durch Amino/

Ketosäuren-Supplemente: Einfluß auf die Proteinurie 26

Hinweise für Autoren.

Giovannetti, S., Pisa/Italy

The Compliance with Supplemented Diet by Chronic Uremics and Their Nutritional Status 4

Bergström, J.; Ahlberg, M. and

Alvestrand, A., Stockholm!Sweden; Fürst, P., Stuttgart

Amino Acid Therapy for Patients with Chronic Renal Failure . . 8

Barsotti, G.; Navalesi, R.; Morelli, E.; Giampietro, O.;

Ciardella, F.; Cupisti, A. and Giovannetti, S., Pisa/Italy

Effects of a Low-Phosphorus, Low-Protein Diet Supplemented

with Essential Amino Acids and Keto Analogues on 'Overt'

Diabetic Nephropathy 12

Walser, M.; LaFrance, N.; Ward, L. and

VanDuyn, BaltimorelU.S.A. 
Progression of Chronic Renal Failure in Patients Given Keto

Acids Following Amino Acids

17

Gretz, N.; Meisinger, E, and Strauch, M., Mannheim

Influence of Diet and Unterlying Renal Disease on the Rate of

Progression of Chronic Renal Failure 21

Meisinger, E.; Gretz, N. and Strauch, M., Mannheim

Hyperfiltration due to Amino and Keto Acid Supplements of

Low-Protein Diets: Influence on Proteinuria 26

Instructions for Authors 29

Gretz, N.; Meisinger, E. und Strauch, M., Mannheim Hyperfiltration unter eiweißarmer Diät induziert durch Amino/ Ketosäuren-Supplemente: Einfluß auf die Kreatinin-Clearance . 30

Gretz, N.; Meisinger, E. and Strauch, M., Mannheim

Hyperfiltration due to Amino and Keto Acid Supplements of

Low-Protein Diets: Influence on Creatinine Clearance 30

Sonderbände

33

Special Editions.

33

Schmicker, R., Rostock/DDR; Vetter, K.; Lindenau, K. und Fröhling, P. T., Potsdam/DDR; Kokot, F., KatowitzlPolen

Konservative Langzeitbehandlung bei chronischer Niereninsuffi zienz mit Ketosäuren- und Aminosäurensubstitution 34

Lindenau, K.; Vetter, K. und Fröhling, P. T., Potsdam/DDR;

Kokot, F., KatowitzlPolen; Schmicker, R., Rostock/DDR

Einfluß von Ketoanalogen auf die renale Osteopathie

40

Schmicker, R., RostocklGDR; Vetter, K.; Lindenau, K. and

Fröhling, P. T., PotsdamlGDR; Kokot, F., KatowitziPoland

Conservative Long-Term Treatment of Chronic Renal Failure

with Keto Acid and Amino Acid Supplementation

Lindenau, K,; Vetter, K. and Fröhling, P. T., PotsdamlGDR;

Kokot, F,, Katowitz!Poland; Schmicker, R., RostocklGDR

Influence of Keto Acid (KA) Treatment on Renal Osteo-

dystrophy

34

40

Gerok, W., Freiburg Hepatische Enzephalopathien

43

Gerok, W., Freiburg Hepatic Encephalopathy

43

Schomerus, H., Rotenburg (Wümme) 
Das Krankheitsbild der hepatischen Enzephalopathie

Egberts, E.-H., Tubingen

Therapeutische Studien mit verzweigtkettigen Aminosäuren bei portosystemischer Enzephalopathie 53

Schwartz, S.; Farriol, M.; Rodriguez, R.; Garcia, E.;

Padró, J. B. und Vente, P. E., Barcelona!Spanien

Einfluß der qualitativen Kalorienzusammensetzung enteraler

Ernährungsformeln auf die hepatische Proteinsynthese bei nor-

malen und operierten Ratten 59

Schauder, P., Göttingen

Bedeutung der verzweigtkettigen Ketosäuren für den Protein-

stoffwechsel 62

50

Schomerus, H., Rotenburg (Wümme) The Symptoms of Hepatic Encephalopathy.

Egberts, E.-H., Tubingen

Therapeutical Trials with Branched Chain Amino Acids in Por-

tosystemic Encephalopathy 53

Schwartz, S.; Farriol, M.; Rodriguez, R.; Garcia, E.;

Padró, J. B. and Vente, P. E., Barcelona/Spain

Influence of the Qualitative Caloric Composition of Enteral

Diets on Liver Protein Synthesis in Normal and Operated Rats. . 59

Schauder, P., Göttingen

Implications of Branched Chain Keto Acids for Protein Metab

olism . 62

Bibliographischer Hinweis: Inhaltsverzeichnisse dieser Zeitschrift erscheinen regelmäßig in

Current Contents9 sowie in anderen bibliographischen Diensten. Infusionstherapie und klinische

Ernährung · Forschung und Praxis · Supplement 5 zu Band 14, Oktober 1987 